\title{
Environmental Health-Based Post-Coal Mine Policy in East Borneo
}

\author{
Absori Absori ${ }^{1}$, Aulia Vivi Yulianingrum ${ }^{2}$, Khudzaifah Dimyati ${ }^{1}$, Harun Harun ${ }^{1}$, Arief Budiono ${ }^{1 *}$, Hari Sutra Disemadi ${ }^{3}$ \\ ${ }^{1}$ Department of Law, Universitas Muhammadiyah Surakarta, Surakarta, Indonesia; ${ }^{2}$ Department of Law, Universitas \\ Muhammadiyah Kalimantan Timur, Samarinda, Indonesia; ${ }^{3}$ Department of Law, Universitas Internasional Batam, Batam,
} Indonesia

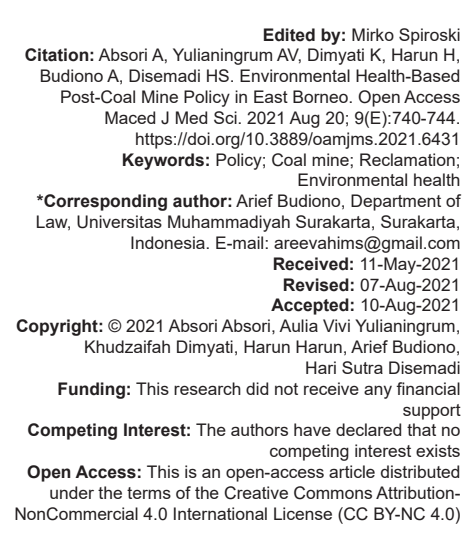

\section{Abstract}

BACKGROUND: Post-coal mine activities must be carried out by considering good management principles, to avoid negative environmental impacts, especially to avoid land surface imbalance, to avoid destruction of flora and fauna, and more importantly, to maintain the public health. The post-mining regulations based on the priorities of public health and environmental sustainability are designed to increase the human resource quality for the interests of regional development.

AIM: This study aims to describe the post-coal mine policy in East Borneo and to formulate the post-coal mine policy as a form of control over ex-mine land from the aspect of environmental health.

METHODS: This study uses the qualitative research design. It is a sociolegal type of research with the case study approach toward the currently developing post-coal mine reclamation. This study uses the fishbone analysis.

RESULTS: The results of this research show that the supervision toward the ex-mines is still weak. It leads to expanding environmental destruction and some of the companies' ignorance toward reclamation and post-mining obligations. This condition impacts the water quality, as it is the people's necessity in fulfilling their basic needs.

CONCLUSION: There needs to be a post-coal mine regulation through policies which prioritize environmental sustainability and public health. It includes the optimization of the ex-mine supervision, new regulations as the implementation of the central government's constitutional regulation, and inspection of environmental health in achieving quality human resources of the region.

\section{Introduction}

The main problem of coal mine management is reclamation and post-mining. Reclamation is constantly carried out during the stages of mining business to reorganize, recover, and improve the quality of the environment and the ecosystem. It is a planned, systematic, and sustainable activity after the end of some or all mining activities to restore the functions of the natural and social environments of the mining [1]. Essentially, the coal mining activity must be carried out by considering the principle of good mining to avoid negative environmental impacts, especially to avoid land surface imbalance. It is also to avoid the destruction of flora and fauna, to avoid climate change, and to maintain public health [2]. Thus, accurate and integrated reclamation and post-mining activities must be implemented as early as possible.

The Indonesian government's law on the enforcement of reclamation and post-mining is stipulated in the Coal and Mineral Law No. 4 of 2009 which is changed into the Law No. 3 of 2020. This law obliges coal mining business owners to guarantee reclamation and to submit reclamation plan documents as a requirement to obtain the Mining Business Permit.
The executing regulation of the Indonesian Mineral and Coal Law is stipulated in the Governmental Decree No. 78 of 2010 on the Implementation of Reclamation and Post-Mining to Mineral and Coal Mining Business Activities. This encouraged various areas in the Indonesian provinces which are rich in coal natural resources to formulate some policies through regional regulations.

The East Borneo Province has a supply of 5.2 million hectares of coal resource [3]. The Indonesian central government stipulated that each province must supply 57 million tons of coal each semester, and East Borneo is able to fulfill this production target. This makes the regional original income depend on the coal mine sector [4].

Natural resource exploitation is not always followed by good environmental restoration: Environmental destruction becomes even more uncontrollable, giant floods inundated all cities in a province; and the ex-mining pits are left opened, causing fatalities. The usage of the ex-mining pits is not according to the condition. For example, quarries are used for fish ponds as well as tourism, meanwhile, backfilled land is used for residential areas. On the one hand, the ex-coal mine usage management concept brings benefits to the surrounding people. On the 
other hand, however, it must be acknowledged that the dangerous substances in the ex-coal mine quarries are hazardous.

Based on Mudhar's research, the current coal mine reclamation policies are only side with the interests of economic values without paying attention to environmental aspects. The regulations are very weak in punishing the business permit owners who fail to complete the reclamation and post-mining obligations [5].

Based on the problems described above, the aims of this research are: (1) to describe the post-coal mining policies in East Borneo and (2) to formulate a post-coal mining policy as a form of control over the ex-mining land from the environmental aspect.

\section{Methods}

This paper is a juridical-empirical research which uses the non-doctrinal qualitative approach. The location of this study is East Borneo, as it is ranked first as the province which issued the most Mining Business Permits in Indonesia. It is also the area for large-scale mining companies through the Coal Mining Concession Work Agreement. The primary data are obtained through the purposive sampling method at certain areas and from chosen informants [6]. The informants in this research are as follows: Head of the Mineral and Coal Sector at the Energy Natural Resource and Mineral Service of East Borneo Province, Head of the Law Enforcement Sector at the Environmental Service of East Borneo Province, and representatives of the Mining Advocacy Network non-governmental organization.

The data of this research are collected through three methods, which are in-depth interviews, observation, and legal document analysis. Additional instruments that the writers use in conducting the interviews include interview guidelines, recording devices, field notes, and camera. The data obtained from the in-depth interview are processed manually based on the qualitative data processing guidelines. Then, the data are analyzed using the content analysis method and then it is interpreted. Finally, the data are presented narratively.

\section{Results}

\section{Post-coal mine policies in East Borneo}

The mining sector is very promising for the growth of the Indonesian economy. The economy of the East Borneo Province is still dominated by the main sector which is coal mining which dominates this province's economic growth [7]

There is an increasing year-over-year trend of East Borneo province's job opportunities in the mining and excavation sector, from $7.19 \%$ in 2018 to $3.38 \%$ in 2019. It significantly increased to $46.29 \%$ in 2020 [8]. The Coal Mining Concession Work Agreement in East Borneo uses up 5.2 million hectares or $40.39 \%$ of East Borneo Province's land.

With this great exploration area, the postmining regulations are aimed to achieve sustainable development by considering the principles of environmental sustainability, transparency, and social participation. The public issues on post-mining and reclamation become the basis for policy formulation [9]. The provincial government issued the East Borneo Province Regional Government No. 8 of 2013 on the Reclamation and Post-Mining Establishment. This refers to the Indonesian Government's Regulation No. 78 of 2010 on Reclamation and Post-Mining. It mandates the East Borneo governor to formulate a commission on reclamation and post-mining supervision.

Informants of this study state that there is a discrepancy between the regulations and the Reclamation Plan documents of the coal mine business owners, thus, the application is not optimum. Only 386 out of 1014 Mining Business Permit owners have implemented post-mining activities. The post-mining reclamation plans are presented in Table 1.

Restoration includes returning the ecosystem which existed before the start of the mining business activities. Rehabilitation includes the creation of a new environment. During this process, there needs to be a long-term supervision and management program to assess the effectiveness of this reclamation, to identify the necessary corrective actions, and to supervise the on-going processes such as water management and gas disposal. Revegetation is the activity of replanting the once existing plants [10]. The problems in the field include lack of reclamation plan documents. Thus, especially in East Borneo, mining pits are everywhere, causing fatalities.

\section{Post-mine policies: Environmental health}

Open coal mines cause the change in the predevelopment environmental condition and it leaves ex-mining pits (void). Without good utilization planning, the void left at the end of the mining activities may cause unwanted impacts for the environment.

The policy on environmental restoration as an impact of coal mine activities became the main agenda of the East Borneo Provincial Government to control the environmental destruction, to achieve independence in sustainably managing natural resources in an environmentally friendly manner [11]. The health vision "For All, for East Borneo People to 
Table 1: Mining Business Permit Post-Mining Reclamation Plans 2018-2020

\begin{tabular}{lllll}
\hline No. & City/regency & $\begin{array}{l}\text { Number of companies } \\
\text { (Mining Business Permit) }\end{array}$ & $\begin{array}{l}\text { Number of reclamation plan } \\
\text { documents (companies) }\end{array}$ & Type of reclamation \\
\hline 1. & Paser & 40 & 27 & Restoration, revegetation \\
2. & North Penajam Paser & 131 & 18 & Restoration, revegetation \\
Rehabilitation & Restoration, rehabilitation, revegetation \\
4. & Samarinda & 26 & 37 & Rehabilitation \\
5. & East Kutai & 128 & 171 & Restoration, rehabilitation, revegetation \\
6. & Kutai Kertanegara & 452 & 77 & Restoration, rehabilitation, revegetation \\
7. & West Kutai & 167 & 23 & 386 \\
& Berau & 70 & & \\
\hline
\end{tabular}

Achieve a Good Degree of Health" is described in four missions which include facilitating the maintenance and the improvement of quality, affordable, and just health efforts, to encourage and to power social empowerment to live healthily and to grow inter-sectoral partnership. To guarantee the implementation of this program, it is monitored by the Regional Public Hospital through law enforcement in the form of administrative sanctions.

The dominating Coal Mine Business Permits in East Borneo causes environmental and health issues. It encouraged the issuing of an environmental healthbased regulation by considering the aspects of healthy and good quality environment to prevent diseases or health issues. According to Puspitasari [12], there is one agenda in decreasing illnesses due to environmental risk factors from coal mine activities, which is Environmental Health Regulation Inspection through:

(a) The implementation of waste disposal permit; (b) supervisory analysis, and (c) law enforcement.

There are some cases in Samarinda City, East Kutai Regency, and Kutai Kertanegara Regency at East Borneo Province which happened due to the ex-coal mine site usage which is not used accordingly, causing disturbances to the people's health as follows:

1. PT. Nuansa Coal Investment. This company caused environmental pollution to the people. The settling pond is not yet adequate; thus, the waste management pollutes the people's wells. The efforts the company has carried out include managing the environment according to the Environmental Management Plan and Environmental Monitoring Plan documents; reclamation has been carried out in the ex-mining site; and it has implemented revegetation. There are three settling ponds equipped with a wastewater disposal permit and temporary storage of hazardous and toxic waste permit. It has routinely carried out monthly wastewater assessment and it has self-monitored the $\mathrm{pH}$ level and daily debit assessment. It has also routinely measured the air quality

2. PT. Insani Bara Perkasa (PT. IBP). Before polluting the environment, the produced waste water was managed by flowing it to the people's area. Thus, the water cannot be used for daily activities. It was deemed as "not compliant" as it violated the obligation to immediately report the routine and punctual implementation of Environmental Management Plan and Environmental Monitoring Plan. PT. IBP has not yet delivered the Environmental Management Plan and Environmental Monitoring Plan implementation report of the fourth quarter in 2015. The waste water management is not yet maximum, but it has already obtained the temporary storage of hazardous and toxic waste permit

3. CV. Bara Energi Kaltim (CV. BEK) did not carry out post-reclamation at ex-coal mine pits. It was imposed with the administrative sanction of business permit revocation by the East Borneo Provincial Government as it did not manage the environment based on the Environmental Management Plan and Environmental Monitoring Plan documents. The waste water management is not maximum, even though it has obtained the waste water disposal permit, but it has not routinely assessed the waste water quality each month. Neither has it assessed the $\mathrm{pH}$ and the daily debit. The settling pond is not well-maintained and it has not assessed the ambient air quality routinely each semester. CV. BEK was also asked to restore the environment [13]

Effectiveness of the post-coal mine supervision is even more crucial with the increasing ignorance of reclamation and post-mining activities in East Borneo. It is due to these factors: First, the regional perceives their roles to be subordinate to the policies issued by the central government and that it is only procedural. Second, there is a lack of development for the consideration of environmental and social awareness. It results in limited access in fulfilling society's need for health.

The basic principle of environmental sustainability which applies the principles of wisdom is as follows:

First, natural resource management needs to be planned according to the environment's supporting power. The spatial planning of some cities/regencies in East Borneo is not according to the principle of environmental health, as the distance between the people's crowded residential areas and the coal mine companies is only $400 \mathrm{~m}$. Thus, the people near the mines are prone to suffer from environmental pollution.

Second, developmental projects which bring negative environmental impacts need to be controlled 


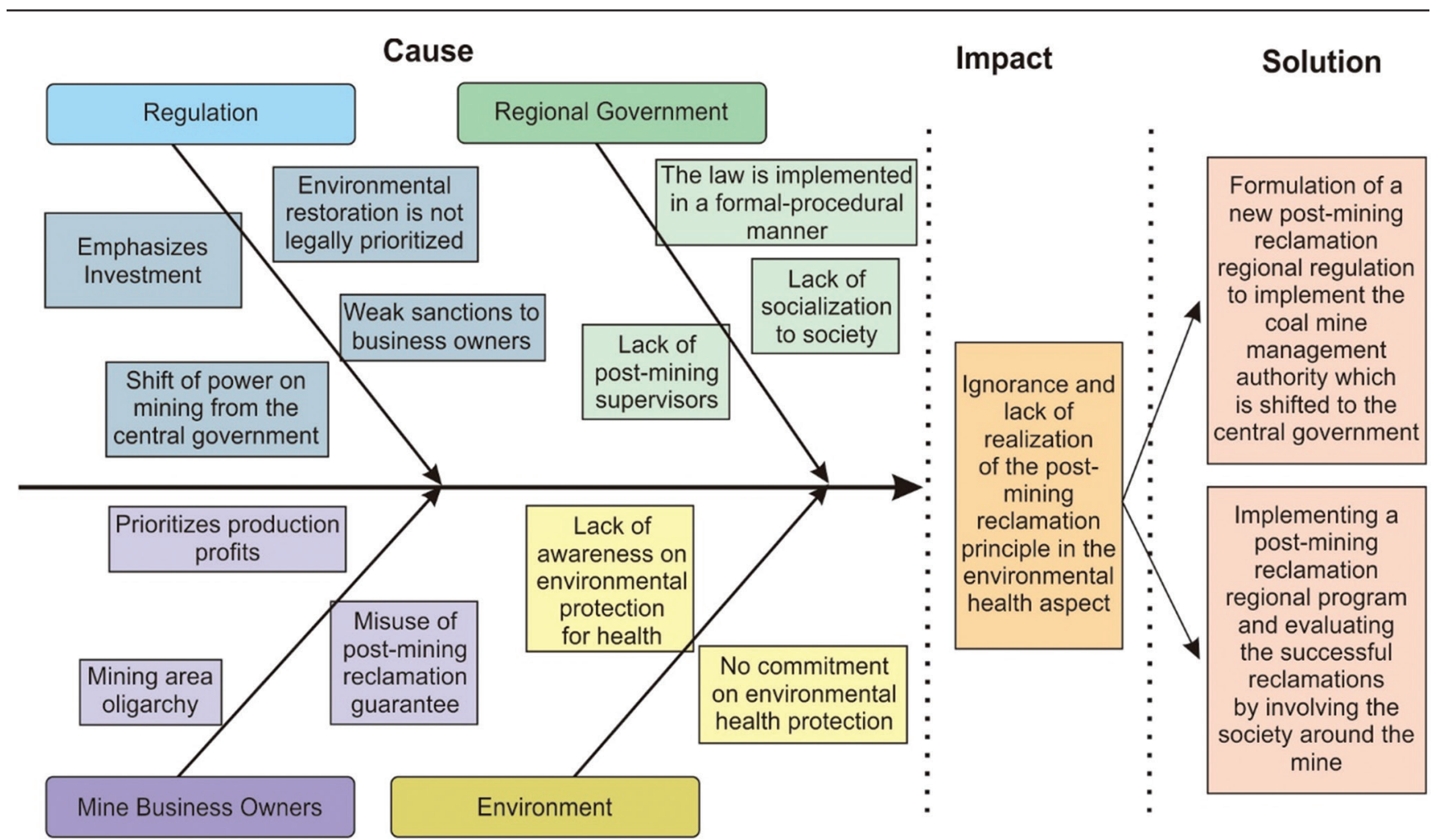

Figure 1: Fishbone diagram analysis

through the application of environmental impact analyses as part of the feasibility study in the process of planning a project.

Third, prioritizing the handling of water, air, and earth pollution through environmental health inspection.

Fourth, the development of biodiversity to stabilize the environment.

Fifth, the development of economic policies which consider the environment and which develop the participation of the society, the institutions, and the labor in managing the environment [14].

The type of policy proposed in this research is a policy model with the fishbone diagram analysis, which helps present a structured visual list that describes the various causes which influence processes. The identification process is carried out by finding the root causes which influence the irrelevant local public health regulations from these indicators: (1) The regional government; (2) the regulations; (3) the mining business owners; and (4) environment.

This instrument may be used by the governmental institutions to identify and to explore the cause of a problem or to find the factors which may direct them to find solutions or improvements.

Based on the fishbone diagram analysis results above, it is found that until now, the East Borneo Provincial Government has not yet issued an implementing regulation on the new post-coal mine regulations as an implementation for the coal mine business management authority which is shifted to the central government. There is also a lack of social participation.

The lack of stipulations causes the companies to ignore post-mining reclamations. The shift of power from the regional governments to the central government makes it difficult for the business owners or the authorities to interpret the ever-changing law implementations. Because of that, guidelines for postmining reclamation activities are necessary for the people's health and for environmental restoration. It will help the stakeholders, the business owners, and the society to understand the implementation of these laws.

The priority of environmental restoration regulation is public health. It is an important element in empowering the quality of human resources in that area. Apart from that, criminal sanctions must be imposed as an ultimum remedium to the coal mine business owners who ignore the post-mining reclamation with a greater reclamation guarantee than that which is currently burdened to them. Then, there needs to be a commitment to maintain the environmental preservation as a moral responsibility for the livelihoods of the future generations. The total awareness in maintaining the riches of nature for the future generations through the usage of post-mining reclamation guarantee must not be used solely for political interests [15].

The regional regulation's implementation is not only for procedural reference in managing the natural resource regulations for the regional authorities. However, it is a form of a sustainable usage in the health and environmental aspects for the regional 
people's livelihoods. This is crucial, considering that the East Borneo Province is the producer of the promising coal commodity which helps the region's economy specifically and the national economy in general. Thus, it must not only focus on seeking profits, but it must participate in maintaining the health of the society.

\section{Discussion}

East Borneo Province has the chance needs achieve quality public health through the implementation of sustainable environmental restoration and public health obligations. Regulations must be issued to oblige business owners in restoring the environment and in maintaining the local people's health. There is a lack of post-mining supervision, causing an expanding environmental destruction. There are also companies which ignore the reclamation and post-mining obligations, thus impacting the water quality. The postmining and reclamation plan documents are principal items as they are requirements for implementing the mining management business permit. It is the regional government's effort in protecting the society to achieve a good public health, which will affect the human resource quality.

The post-coal mine policy model which is analyzed using the fishbone diagram may help explain and describe various causes of a problem. It shows the weak monitoring system and the lack of sanction impositions to the coal mine business actors. This instrument may be used by the governmental institutions to identify and to explore the cause of a problem or to find the factors which may direct them to find solutions.

\section{Recommendation}

Companies are obliged to hand over reclamation and post-mining guarantees before carrying out the coal mine business activities. The companies must implement CSR in the form of health facility completion for the people around the mine.
There is priority over the recovery of the forest area function by prioritizing revegetation or replanting the once existing trees. The government must tighten the mining business permit requirements and the permit's validity period must be limited. There is the imposition of administrative sanctions in the form of mining business permit revocation for companies who fail to hand over the Reclamation Plan documents.

\section{References}

1. Republic of Indonesia's Governmental Decree No. 78 of 2010 on Reclamation and Post-Mining; 2010.

2. Arsyad S, Rustiadi E, editors. Saving the Earth, Water, and Environment. Yogyakarta: Yayasan Pustaka Obor; 2008.

3. Sonny S, Wardhana I. Mining and deforestation: Study of coal mine permit in East Borneo province. Renaissance. 2020;5:681-90.

4. Lung F. East Borneo Coal Mine Energy Source as to Support the New Capital City's Economy. Jakarta: Perhapi; 2020. p. 425-34.

5. Muhdar M. Coal mine reclamation legal aspect in forests of East Borneo. Mimbar Hukum-FH UGM. 2015;27:472-86.

6. Faisal S. Formats of Social Research Basics and Application. Depok: Rajawali Pers; 1989

7. Zaini A. Development of the Prioritized Sector in East Borneo Yogyakarta: Deepublish; 2019.

8. Statistics Indonesia. East Borneo in Numbers. Samarinda: BPS 2017.

9. Osman S, Yang CN, Abu MS, Ismail N, Jambari H, Kumar JA. Enhancing students' mathematical problem-solving skills through bar model visualisation technique. IEJ Math Educ. 2018;13(3):273-9. https://doi.org/10.12973/iejme/3919

10. Wicaksono MB. Effectivity of Administrative Law Enforcement towards the Coal Mine Reclamation and Post Mining Violation in East Borneo. Doctoral Dissertation, UNS; 2020

11. East Borneo Regional Regulation No. 10 of 2016. Mid-Term Development Plans 2016-2021; 2021.

12. Puspitasari DE. Impacts of water pollution towards environmental health: Perspective of environmental law. Mimbar Hukum-FH UGM. 2009;21:23-34.

13. Kotijah S. Lawsuit to Coal Mine Companies. Samarinda: PostCoal Mine Supervisory Commission; 2012.

14. Absori A. Declaration of Sustainable Development and its Implication in Indonesia. Yogyakarta: Genta; 2009.

15. Absori A, Nugroho SS, Haryani AT, Sarjiyati S, Budiono A, Nugroho HS, et al. The prospect of environmental law to achieve healthy environmental development in Indonesia. Medico Legal Update. 2020;20(1):204-8. 